Australian

National

University

Crawford School of Public Policy

\title{
CAMA
}

Centre for Applied Macroeconomic Analysis

\section{The Trade Effects of Tariffs and Non-Tariff Changes of Preferential Trade Agreements}

\section{CAMA Working Paper 49/2017}

\section{August 2017}

\section{Juyoung Cheong}

Department of Economics, Kyung Hee University, Korea

Do Won Kwak

Asiatic Research Institute, Korea University

\section{Kam Ki Tang}

School of Economics, University of Queensland and

Centre for Applied Macroeconomic Analysis, ANU

Keywords

Preferential Trade Agreements, Tariff, Non-tariff Measure, Gravity Model

JEL Classification

F15

Address for correspondence:

(E) cama.admin@anu.edu.au

ISSN 2206-0332 


\section{Abstract}

The recent literature on preferential trade agreements (PTAs) emphasizes the distinction between the extensive and intensive margins. What has been missing is the distinction between tariff and non-tariff changes under PTAs. Tariff reduction is a quintessential feature of PTAs. But member countries of a PTA often pursue deeper integration through agreements on nontariff matters as well. Some member countries, however, may want to use non-tariff barriers to compensate for tariff cuts. The current study isolates the effects of tariff and non-tariff changes under PTAs. It involves the construction of a new dataset of bilateral tariff rates for 90 importing and 149 exporting countries over 1996-2010, covering the Harmonized System 2-digit level of product varieties. Given the complexity of non-tariff arrangements, we allow for heterogeneity across three different types of PTAs, namely custom unions (CUs), free trade agreements (FTAs), and partial scope agreements (PSAs). We further consider heterogeneity within each of these three PTAs regarding responding time, partner type, and product type. The key findings are: (i) nontariff changes under PTAs on average increase both the intensive and extensive margins of trade; (ii) PSAs do not have discernible trade impacts unlike FTAs and CUs; (iii) CUs have a stronger trade impact than FTAs; (iv) the impact of CUs comes mostly from non-tariff changes, while that of FTAs comes from both tariff and non-tariff changes; (v) non-tariff changes associated with CUs have a stronger trade effect than those associated with FTAs, which in turn are stronger than those associated with PSAs; (vi) non-tariff changes take a longer time than tariff changes to impact on the intensive margin; (vii) non-tariff changes under FTAs and CUs between industrial and developing countries increase the exports from the former to the latter more than the other way around; and (viii) there is substantial heterogeneity across sectors in their response to trade liberalization.

The Centre for Applied Macroeconomic Analysis in the Crawford School of Public Policy has been established to build strong links between professional macroeconomists. It provides a forum for quality macroeconomic research and discussion of policy issues between academia, government and the private sector.

The Crawford School of Public Policy is the Australian National University's public policy school, serving and influencing Australia, Asia and the Pacific through advanced policy research, graduate and executive education, and policy impact. 


\title{
The Trade Effects of Tariffs and Non-Tariff Changes of Preferential Trade Agreements*
}

\author{
Juyoung Cheong`, Do Won Kwakł and Kam Ki Tang ${ }^{\S}$
}

August 10, 2017

\begin{abstract}
The recent literature on preferential trade agreements (PTAs) emphasizes the distinction between the extensive and intensive margins. What has been missing is the distinction between tariff and non-tariff changes under PTAs. Tariff reduction is a quintessential feature of PTAs. But member countries of a PTA often pursue deeper integration through agreements on nontariff matters as well. Some member countries, however, may want to use non-tariff barriers to compensate for tariff cuts. The current study isolates the effects of tariff and non-tariff changes under PTAs. It involves the construction of a new dataset of bilateral tariff rates for 90 importing and 149 exporting countries over 1996-2010, covering the Harmonized System 2-digit level of product varieties. Given the complexity of non-tariff arrangements, we allow for heterogeneity across three different types of PTAs, namely custom unions (CUs), free trade agreements (FTAs), and partial scope agreements (PSAs). We further consider heterogeneity within each of these three PTAs regarding responding time, partner type, and product type. The

*This work was funded by a grant from Kyung Hee University in 2016 (KHU-20161391) and the National Research Foundation of Korea Grant from the Korean Government (NRF-2008-362-A00001).

$\dagger$ Corresponding author; Department of Economics, Kyung Hee University, Korea; e-mail:

¥Asiatic Research Institute, Korea University, Seoul, Korea; e-mail: dwkwak@korea . ac.kr

${ }^{\S}$ School of Economics, University of Queensland, QLD 4072, Australia; e-mail: kk . tang@uq. edu . au.

ICentre for Applied Macroeconomic Analysis, Australian National University, ACT 2061, Australia.
\end{abstract} jcheong@khu.ac.kr 
key findings are: (i) non-tariff changes under PTAs on average increase both the intensive and extensive margins of trade; (ii) PSAs do not have discernible trade impacts unlike FTAs and CUs; (iii) CUs have a stronger trade impact than FTAs; (iv) the impact of CUs comes mostly from non-tariff changes, while that of FTAs comes from both tariff and non-tariff changes; (v) non-tariff changes associated with CUs have a stronger trade effect than those associated with FTAs, which in turn are stronger than those associated with PSAs; (vi) non-tariff changes take a longer time than tariff changes to impact on the intensive margin; (vii) non-tariff changes under FTAs and CUs between industrial and developing countries increase the exports from the former to the latter more than the other way around; and (viii) there is substantial heterogeneity across sectors in their response to trade liberalization.

JEL Code: F15

Keywords: Preferential Trade Agreements, Tariff, Non-tariff Measure, Gravity Model

\section{Introduction}

Preferential trade agreements (PTAs) have dramatically proliferated since the mid-1990s, prompting numerous studies on their effects. Most studies, including Baier and Bergstrand (2007, 2009), Magee (2003, 2008) Eicher et al. (2012) and Cheong et al. (2015a,b), find the effects on trade volume between PTA signatures to be significant and positive, with Ghosh and Yamarik (2004) being an exception. The recent literature goes beyond trade volume and emphasizes the distinction between the intensive and extensive margins of trade (Eaton and Kortum, 2002; Melitz, 2003; Chaney, 2008). Dutt et al. (2013) show that the growth in trade since the 1980s has been largely driven by trade in new products (i.e. the extensive margin) instead of by the growth in old products (i.e. the intensive margin). Some studies find that product variety is an important source of gains from trade (e.g. Broda and Weinstein 2006), but some others suggest otherwise (e.g. Arkolakis et al. 2012).

Studying the extensive margin of trade requires disaggregate data at the firm, industry or prod- 
uct level, as seen in Trefler (2004), Bernard et al. (2009) and Kehoe and Ruhl (2013). Because these studies focus on a few selective countries, their findings cannot be generalized to others. Dutt et al. (2013) cover a large number of countries over a long period, but their focus is on the World Trade Organization (WTO) membership instead of PTAs. Foster et al. (2011) and Baier et al. (2014) are two exceptions, investigating the PTA effects on the product margins covering a substantial number of countries.

What has been missing in the aforementioned studies is the distinction between tariff and nontariff changes under PTAs. Tariff reduction is a quintessential feature of PTAs as member countries aim to gain better access to each other's market. However, member countries often pursue "deeper integration" through agreements on non-tariff matters as well. Non-tariff measures (NTMs) typically cover competition policies, product standards, regulatory regimes, investment codes, environmental policies, labor standards and so on. ${ }^{1}$ Ex ante the trade effect of NTMs can be either positive or negative. On the one hand, legally binding agreements can reduce uncertainty for traders arising from unilateral policy interventions (Bagwell and Staiger, 2002). On the other hand, some member countries may use NTMs to protect import-competing industries, especially those with strong lobbying power. Under the General Agreement on Tariffs and Trade (GATT), PTAs are allowed as an exception to the clause of Most Favored Nation (MFN) only if all duties are eliminated on "substantially all" trade between the member countries within a "reasonable length of time". As such, countries wanting to protect specific industries can only resort to non-tariff barriers (NTBs) disguised as GATT-complying NTMs. Ray (1981) provides empirical evidence that NTBs have been utilized in part to compensate for internationally agreed-upon tariff reductions, and Limao and Tovar (2011) show that tariff commitments in trade agreements increase the likelihood and restrictiveness of NTBs.

In fact, NTBs have risen during the mid-1990s to 2000 and then again after the Global Financial Crisis (WTO, 2012). And there has been a steady increase in sanitary and phytosanitary (SPS) measures and technical barriers to trade (TBTs) notifications by WTO members since 1995

\footnotetext{
${ }^{1}$ See pp. 78 of Baier and Bergstrand (2007) for the related literature.
} 
(Bacchetta and Beverelli, 2012). Because the GATT and WTO have already reduced tariffs substantially, as evident in the merely five percent average duty worldwide, tariff reduction arising from future PTAs will be moderate; consequently, NTMs may become increasingly important in determining the impact of PTAs.

Against this background, the objective of this paper is to examine the effects of tariff and nontariff changes ${ }^{2}$ under PTAs on trade flows and product margins of trade. If non-tariff changes are found to have positive effects on trade, then it implies that countries' liberalization is beyond what the GATT initially aimed to accomplish through tariff reduction; if the effects are negative, it is the other way around. In the scenario that both tariff and non-tariff changes has positive trade effects, it is useful to compare their quantitative differences. This is because the negotiation for a PTA usually takes years to conclude, and NTMs are often the most time-consuming items, therefore, it is important to know how those efforts on NTM negotiation pay off regarding trade gain. Nontariff barriers are one but not all sources of non-tariff changes associated with PTAs. Preferential trade agreements could be a form of commitment to more stable and predictable policies, making firms more likely to incur the fixed costs of selling in the market. Signatory governments of a PTA may also implement some economic reform policies to complement a PTA.

The empirical strategy adopted in this paper is able to separate the effects of NTMs associated with PTAs from the effects of potential complementary policy changes using import-country fixed effects (FEs). Using this strategy, we first estimate the effects of PTAs as a composite, and then separate it into two distinct components: the effect from tariff-cut and the effect from other remaining policy (i.e. non-tariff) changes associated with the adoption of PTAs, respectively. We focus on the heterogeneity in non-tariff changes by distinguishing three types of PTAs, namely partial scope agreements (PSAs), free trade agreements (FTAs), and custom unions (CUs). In our framework, the estimated effect from tariff cuts is common to all PTAs while that from other remaining policy changes is the average effect from various non-tariff changes for each type of PTA. We test, regarding the degree of economic integration, whether CUs dominate FTAs which in turn dominate

\footnotetext{
${ }^{2}$ For simplicity, we use "non-tariff changes" to denote "changes in non-tariff measures".
} 
PSAs. Baier et al. (2014) find that CUs, which provide the deepest form of economic integration among the three, have the largest effects on bilateral trade. However, it is not entirely clear whether the results are due to CUs entailing the deepest tariff cut or the deepest non-tariff changes or both. It is also not clear, regarding the quantitative effects on trade, how the three types of PTA fare relative to each other. Equally unknown is the relative importance of tariff and non-tariff changes associated with each type of PTA and across different types of partner, e.g. industrial-industrial countries versus industrial-developing countries. In this paper, we aim to provide answers to these questions.

To our knowledge, this paper is one of the first studies to isolate the trade effects of tariff and non-tariff changes associated with PTAs in a gravity equation framework and to differentiate PTAs among and between developing countries and industrial countries. Such differentiations are important if there is uneven bargaining power between them. For instance, Bergsten (1997) asserts that in the North America Free Trade Agreement (NAFTA) negotiation, Mexico "accepted virtually every demand placed upon it" and "made virtually all the concessions." In addition, we consider the lagged effects of trade integration. Because NTMs tend to be more complex as well as heterogeneous than tariffs, countries may take a longer time to respond to non-tariff changes than to tariff cuts. Lastly, we also consider the sectoral heterogeneity in countries' responses to trade liberalization.

To accomplish our objective, we have constructed a comprehensive bilateral tariff dataset covering 90 importing and 149 exporting countries over the period of 1996 to 2010 at the Harmonized System 2-digit (HS2) level. The dataset allows us to compute the average tariff rates on goods between any two WTO member countries. This dataset also allows us to contribute to the recent trade literature on the fixed and variable trade costs (Melitz, 2003; Chaney, 2008). Baier et al. (2014) show that the elasticity of variable costs is larger for the intensive margin than for the extensive margin. Dutt et al. (2013) show that while the extensive margin increases with a drop in either the fixed costs or the variable costs, the intensive margin decreases with a drop in the fixed costs, but its response to a drop in the variable costs is ambiguous. Inferring from their empirical 
findings, they argue that the WTO membership incurs a reduction in the fixed costs for developing countries and a reduction in the variable costs for industrial countries. However, when merely a dummy variable for PTAs (or WTO memberships for that matter) is used in the gravity equation to capture changes in trade costs, it is not clear if it is capturing the fixed costs or the variable costs or both. In other words, the effects of fixed and variable costs as identified in the current literature are mostly based on deduction instead of detection. Our contribution here is that, by separating tariff from NTMs, we can explicitly examine the trade effects of changes in the variable costs because of tariff reduction. ${ }^{3}$

Our key findings are: (i) non-tariff changes under PTAs on average increase both the intensive and extensive margin of trade; (ii) PSAs do not have discernible trade impacts unlike FTAs and CUs; (iii) CUs have a stronger trade impact than FTAs; (iv) the impact of CUs comes mostly from non-tariff changes, while that of FTAs comes from both tariff and non-tariff changes; (v) non-tariff changes associated with CUs have a stronger trade effect than those associated with FTAs, which in turn are stronger than those associated with PSAs; (vi) non-tariff changes take a longer time than tariff changes to impact on the intensive margin; (vii) non-tariff changes under FTAs and CUs between industrial and developing countries increase the exports from the former to the latter more than the other way around; and (viii) there is substantial heterogeneity across sectors in their response to trade liberalization.

The rest of the paper is organized as follows. Section 2 explains our empirical model. Section 3 describes the dataset. Section 4 reports the empirical findings. The last section concludes.

\footnotetext{
${ }^{3}$ We cannot explicitly examine the trade effects of changes in the fixed costs using NTMs, because non-tariff changes could affect either the fixed costs or the variable costs or both. For instance, compiling with pre-shipment inspection or the rule of origin incurs fixed administrative costs, but alternating product material or design to meet higher health or environmental standards could incur both fixed and variable costs.
} 


\section{Methodology}

\subsection{Gravity Model}

Our empirical analysis is based on extending the standard, three-dimensional (importer, exporter, time) gravity equation to incorporate the fourth dimension (product):

$$
\begin{aligned}
\ln T_{i j k t}= & \beta+\gamma_{1} \ln \left(1+\operatorname{Tariff}_{i j k t}\right)+\gamma_{2} P S A_{i j t}+\gamma_{3} F T A_{i j t} \\
& +\gamma_{4} C U_{i j t}+u_{i t}+v_{j t}+w_{i j}+x_{k t}+\epsilon_{i j k t}
\end{aligned}
$$

where $T_{i j k t}$ is the imports of product $k$ at the HS2 level by country $i$ from country $j$ in year $t$; $P S A_{i j t}$ is a dummy taking a value of one if $i$ and $j$ are part of at least one PSA in year $t$ and zero otherwise, and likewise for $F T A_{i j t}$ and $C U_{i j t},{ }^{4} \operatorname{Tariff}_{i j k t}$ is the average tariff of all product varieties at the HS2 level (details of its construction are in the following subsection); $u_{i t}, v_{j}, w_{i j}$, $x_{k t}$ are the importer-time, exporter-time, pair, and product-time fixed effects (FEs); and $\epsilon_{i j k t}$ is the error term.

In eq.(1), $\ln T_{i j k t}$ is the log value of trade flows and a measure of the intensive margin. The estimation of (1) uses only observations of positive trade flows. We supplement the analysis by using the extensive margin as the second trade flow variable. The extensive margin is measured by a dummy variable that is equal to one if $T_{i j k t}>0$ and zero otherwise. That is, for the extensive margin, we estimate a linear probability model and use observations of positive as well as zero trade flows. We prefer linear probability model estimation over logit and probit because it is difficult to account for unobserved factors $u_{i t}, v_{j t}, w_{i j}, x_{k t}$ with logit and probit specifications due to the potential incidental parameter problem (Neyman and Scott, 1948) as well as computational issues with many dummy variables. Furthermore, as long as our main interest is the average partial

\footnotetext{
${ }^{4}$ If the two countries are part of more than one PSA in year $t$, we only count it as one because any extra PSA is redundant as far as the same two countries are concerned. Likewise for FTAs and CUs.
} 
effects for the conditional mean model, the approximation of the linear probability model is quite robust to distributional misspecification on the error term (Angrist and Pischke, 2009; Wooldridge, 2002).

The first three FEs, $u_{i t}, v_{j t}$, and $w_{i j}$, subsume all standard country level explanatory variables in gravity equations. More importantly, $u_{i t}$ and $v_{j t}$, supplemented with $x_{k t}$, are used to capture the multilateral resistance terms (MRTs) (see Anderson and van Wincoop 2003; Magee 2008; Eicher et al. 2012; Dutt et al. 2013; Baier et al. 2014, and among others).

As mentioned in the Introduction, there is a possibility that a country signing a PTA will implement other complementary policy reforms. To the extent that those reforms are not controlled for by FEs and observed covariates, the PTA variables in eq.(1) will over- or understate the true impact of NTMs of the PTA. However, if those complementary policies are non-discriminatory, they should impact on the country's trade with its PTA partner countries as well as its trade with non-partner countries. If that is the case, then the country-time FEs will be sufficient to control for any unilateral policy changes, leaving the PTA variables to capture the effects of bilateral NTMs. Only in the scenario that the policy changes are complementary uniquely to the PTA, trade with partner countries is likely to be affected more. However, in that (rather unusual) scenario, those policy changes are effectively NTMs of the PTA.

It is worth noting that Tariff $f_{i j k t}$ in (1) includes not only preferential tariffs through PTAs and other preferential agreements on tariffs, but also MFN tariffs for pairs with no preferential tariffs. However, $\gamma_{1}$ captures only the effects of preferential tariffs, because MFN tariffs, which are importer-time varying, are controlled for by the importer-time FEs, $u_{i t}$.

It should be noticed that the coefficient on $\ln \left(1+\operatorname{Tariff}_{i j k t}\right)$ is not the marginal effect of tariff changes on trade flows. That is, a $1 \%$ increase in tariffs is not expected to increase trade flows by $\gamma_{1}$ percents. To see that, consider the following simple case. The price of import $k$ in destination $i$ at time $t, P_{i j k t}$, can be represented as

$$
P_{i j k t}=P_{k t} \times E_{i t} \times\left(1+\text { Tariff } f_{i j k t}\right)
$$


where $P_{k t}$ is the international price of product $k$ expressed in USD; $E_{i t}$ is the value of the USD in terms of the currency of country $i$; and Tarif $f_{i j k t}$ is expressed in decimal points.

It is reasonable to assume $T_{i j k t}$ to be a function of $P_{i j k t}$ and thus $\ln T_{i j k t}$ to be a function of $\ln P_{k t}, \ln E_{i t}$, and $\ln \left(1+\right.$ Tarif $\left._{i j k t}\right)$. In (1), the FE terms $u_{i t}$ and $x_{k t}$ subsume $\ln E_{i t}$ and $\ln P_{k t}$. Therefore, $\gamma_{1}$ is the marginal effect of $1 \%$ increase in the domestic price of product $k$ in destination $i$ at time $t$ as a result of certain amount of tariff increase on the product.

\section{Data}

Our dataset has bilateral trade data for 90 importing and 149 exporting countries spanning from 1996 to 2010. The full list of the countries is provided in the Appendix. This sample is chosen based on tariff data availability after the WTO establishment. The country coverage is limited to WTO members because in principle MFN tariff data are applicable only when both importing and exporting countries are WTO members.

Bilateral trade flows and applied bilateral tariffs at the HS6 level, which is the most disaggregate product level in the international standard, are first constructed using data from the World Integrated Trade Solution (WITS). Data from WITS in turn are originally sourced from the UNCTAD Trade Analysis Information System (TRAINS), and WTO's Integrated Data Base (IDB) and Consolidated Tariff Schedules (CTS) data base. After we have constructed the trade and tariff data at the HS6 level, we compute the simple average of them at the HS2 level for our analysis.

Bilateral trade flows are not observable for more than $70 \%$ in our observations at the HS2 level. In cases where positive trade flows are not reported, we impute trade flows as zero if tariffs are reported, and leave them as missing observations if tariffs are not reported. The dataset has nearly 19 million observations, out of which about $24 \%$ are of positive values, about $57 \%$ are zeros, and about $19 \%$ are still missing after imputation.

MFN tariffs and preferential tariffs are separately constructed. MFN tariff are available at the unilateral level, while we need bilateral tariffs. To obtain bilateral tariff data, for each year we 
apply an importing country's MFN tariffs to all its trading partner countries in our sample. This procedure is justifiable as our sample includes WTO members only. For countries engaged in a $\mathrm{CU}$, tariff schedules are available at the union level, not the country level. We therefore use these CU tariff data to generate MFN tariff data for each of the member countries of a CU. Also, for some countries, MFN tariffs are not reported for certain years. In those cases, we use the data from the closest previous available year as a substitute.

Preferential tariffs are collected separately for applicable country-pairs for each year. For most country-pairs preferential tariffs are not equal to zero for many products unless they belong to the same CU. If preferential tariffs on certain products imposed by an importing country are applied to multiple exporting countries simultaneously, data are observed at the group level only. To identify which countries belong to a specific group, we use the Preference Beneficiaries data from TRAINS and then generate preferential tariff data for each country-pair. Like MFN tariffs, for the countries engaged in a $\mathrm{CU}$, we only observe the preferential external tariff schedules at the union level. Therefore, we generate an individual member country's bilateral tariff data using the CU tariff data. Preferential tariffs are also not always reported for all years for many countries, so we use the data from the closest previous available year as a substitute for an unavailable year.

For a given country-pair, product and year, if data for both MFN and preferential tariffs are available, the latter is lower with only a few exceptions. So we use the preferential tariffs if they exist. Otherwise, MFN tariffs are used. ${ }^{5}$

Preferential trade agreements data are constructed from the Regional Trade Agreements Information System (RTA-IS) of the WTO. Data on nominal GDP and GDP per capita are drawn from the Penn World Table (PWT) 7.0. Data on distance, common language, common colony, common border, common legal origin, and country-pair combined land area are drawn from the CEPII. For the country classification based on the income level, we follow Subramanian and Wei (2007).

Table 1 provides the summary statistics for the key variables. The statistics show that, for our

\footnotetext{
${ }^{5}$ Alternatively, we have also used preferential tariffs whenever they are available, otherwise we use MFN tariffs. The difference it makes to the tariff variable after averaging over all products is negligible.
} 
dataset, on average any two countries trade about $29 \%$ of HS2 sectors and the median imports by one country from another is around USD 133,000. The average tariff rate is about $9 \%$ while the median is only $5 \%$. The large difference between the two is due to some exceptionally high tariffs imposed on a specific sector by a few countries. For instance, Egypt's tariff level on spirits (HS2) ${ }^{6}$ is $1,686 \%$ while even a few advanced countries including Canada and the USA impose higher than $100 \%$ tariff on some agricultural products. FTAs and PSAs are more common than CUs.

Figure 1 shows the time trends of the mean values of tariffs, MFN tariffs and preferential tariffs of our sample. MFN tariffs are relatively much higher in 1996 compared to average preferential tariffs and have been substantially reduced by 2010. The rapid decline in MFN tariffs is the reason why the average tariff for the whole sample also reduces at roughly the same rate.

Figure 2 shows the distribution of tariffs in 1996 and 2010, respectively, for sectors at the HS2 level. While tariffs are lower in 2010 on average, tariffs are evenly declined across sectors. One of the few exceptions is sector 22. It is because of Egypt, which has exceptionally high tariff rates, entering the dataset in 2006.

Figure 3 shows the distribution of tariffs in 1996 and 2010, respectively, for several countrypair groupings. Tariffs imposed by industrial countries on each other or developing countries are relatively small even in 1996 and remain so in 2010. Tariffs imposed by developing countries on each other or industrial countries, on the contrary, are much higher in 1996 and, despite substantial reduction over time, are still substantial in 2010. These figures suggest that it might be important to differentiate country-pairs based on whether the importing or exporting countries are developing or industrial countries.

Table 2 shows the summary statistics of the tariff rates among PTA partner countries one year prior, one year after, and five years after the formation of a PTA. The average tariff rate among PSA members only drops by about one percentage point one year before and after the agreement and by another 2.8 percentage points after five years. The average tariff rate among FTAs drops

\footnotetext{
6"Spirits" is coded 22 under Section IV of the HS2 classification. In Table 7 of this paper, it is grouped under "Prepared Foodstuffs".
} 
by similar amounts: 1.5 percentage points and 0.65 percentage points, respectively. But the mean tariff rate hides the fact that tariffs among FTA member countries are much more skewed by the maximum tariff rate in our sample, which is 10 times higher for FTAs than for PSAs. Typically agricultural products attract the highest tariff rates. However, in our dataset, the most prohibitive tariff rate $(1,686 \%)$ is imposed on alcohol - by a Muslim country, Egypt. The 0.5 quantile (median) and 0.75 quantile figures show that tariff rates on most of the products traded among FTA member countries are much lower than their PSA counterparts, as well as reduce faster as a result of their trade agreements.

The tariff rates among CU member countries, as expected, are lowest among the three types of PTAs. The figures show that half of the products traded among the members are effectively not taxed (median tariff $=0.07 \%$ ) even before the formation of the CUs and at least $75 \%$ of the goods traded are not taxed one year afterwards. But the statistics also show that, even though CU members are supposed to impose zero tariffs on each others' exports, exemptions do exist in reality. Nevertheless, overall the findings confirm that, as far as tariff rates are concerned, CUs are a deeper form of economic integration than FTAs, which in turn are deeper than PSAs. The remaining question is whether for NTMs the three types of PTAs exhibit the same order of economic integration. We will answer this question in the following empirical section.

\section{Results}

\subsection{Preferential Trade Agreement Effects on Trade}

Table 3 shows the first set of OLS and FE regression results. Here we include only the three PTA variables and therefore they capture the effects of both tariff and non-tariff changes from the PTAs. The intensive margin of trade is the dependent variable in the first three columns, and likewise for the extensive margin in the last three columns.

Starting with the intensive margin, column (1) reports the OLS regression results. Standard 
gravity equation variables including $\log$ GDP for importer and exporter ( $\operatorname{lgdp} 1 \& \operatorname{lgdp} 2), \log$ GDP per capita for importer and exporter (lgdppc1 \& lgdppc2), contiguity (contig), common coloniser (comcol), common legal origin (comleg), and log distance (ldist) are all significant at the $1 \%$ level and have the expected signs. Both the quantitative and qualitative results from the OLS regression are comparable with the findings of some previous studies with more control variables, e.g. Baier and Bergstrand (2009) and Egger and Pfaffermayr (2003). These findings on the standard gravity variables suggest that there are no serious specification issues and no abnormality about our dataset. As regarding the key PTA variables, PSA is significant at the 5\% level but of a negative sign, while both FTA and CU are significant at the $1 \%$ level and of the expected positive sign. The results suggest that forming a PSA can reduce bilateral trade flows by nearly $10 \%$ between member countries, while an FTA and a CU can lift their trade flows by nearly $22 \%(=\exp (0.198)-1)$ and $92 \%(=\exp (0.65-1))$, respectively. It should be noted that the effects of the PTA variables on the intensive margin are not equal to their regression coefficients. This is because the PTA variables are dummies and their values can change only from zero to one. Because the intensive margin is measured on the logarithmic scale, the trade effect of a PTA variable is equal to the exponential value of its coefficient minus one. However, if the coefficient is small, e.g. less than 0.1 , its value will change little by the exponential transformation. The same argument applies to other intensive margin regressions in this paper but, as explained later, not to the extensive margin regressions.

Column (2) incorporates pair $(i j)$, importer-time $(i t)$ and exporter-time $(j t)$ FEs. These FEs subsume not only all the observed gravity variables in column (1), but also unobserved ones like economic uncertainty. Furthermore, the country-time FEs provide a simple mean to account for MRTs at the aggregate level. With the three FEs, the PSA variable becomes insignificant. Both the FTA and CU variables remain significant at the $1 \%$ level. While the magnitude of FTAs' trade effect has dropped substantially to only $5.5 \%$, that of CUs' has reduced moderately to about $80 \%{ }^{7}$

\footnotetext{
${ }^{7}$ In columns (2) and (3), the $i j$ FEs are handled using within transformation while the $i t, j t$ and $k t$ FEs are handled using dummy variables. The fact that the $R^{2}$ statistics drop significantly in column (2) as compared to column (1) indicates that a lot of variation in the dependent variable is along the $i j$ dimension. Furthermore, the fact that the $R^{2}$ statistics rebound so much in column (3) indicates that a lot of variation is also along the $k t$ dimension.
} 
The differences between the results in columns (1) and (2) indicate that it is important to control for unobserved factors in the estimation of the PTA effects.

Column (3) further incorporates product-time $(k t)$ FEs to account for any unobserved factors at the product-time level like world prices. However, the results are largely the same as column (2), indicating that, at least for our HS2 data, controlling for product-time heterogeneity does not add much to the PTA effect estimation once pair and country-time heterogeneity have been accounted for. The results in column (3) suggest that forming an FTA could raise bilateral trade flows among member countries merely by about $6 \%$, but a CU could increase them by $79 \%$, close to 13 times as big.

Why does the gain from FTAs drop so much (from $22 \%$ to $6 \%$ ) once we have controlled for a few FEs? One possible explanation is endogeneity due to reverse causality. Countries that are natural trading partners tend to form PTAs (e.g. see Cheong et al. (2015b); Magee (2003)). In other words, those trading partners that have unobserved fundamental factors leading to more benefits from forming an FTA are also more likely to do so. To the extent that standard observable gravity variables in column (1) do not fully capture all the fundamental factors underlying bilateral trade potentials, the FTA variable works as a proxy for the unobserved fundamental factors. Therefore, the results in column (1) overstate the real impact of FTAs on bilateral trade. As the FEs in column (2) provide a more comprehensive control over those factors, the estimated trade effect of FTA has substantially reduced. The same mechanism can also work for CUs although the magnitude of the change in coefficients can be different. Indeed, as for the CU variable, controlling for the same set of FEs diminishes its coefficient only slightly (from 0.65 to 0.58 ). This finding suggests that the formation of CUs among some of our sample countries tends to occur more often than the member countries' fundamental factors implied. In other words, the decision to form a CU is not that strongly related to unobserved fundamental factors, as compared to FTAs.

Turning now to the extensive margin, it should be noted that here we use a simple linear probability model and therefore the dependent variable is not expressed in the logarithmic scale anymore. As a result, a coefficient can be interpreted directly as the marginal effect of the corresponding vari- 
able on the average probability of new products being traded, regardless of whether the independent variable is the tariff or the PTA variable. For instance, according to the OLS regression results in column (4), a $1 \%$ increase in the distance between two countries is expected to reduce their chance of trading a product by about $0.08 \%$. Again, all the standard gravity variables have their expected sign if there is one. As for the PTA variables, PSA, FTA, and CU are all significant at the 1\% level, but PSA once again has an unexpected negative sign. However, once FEs are included as in columns (5) and (6), the PSA variable becomes insignificant, the FTA variable becomes significant at the $5 \%$ level only, while the CU variable remains significant at the $1 \%$ level. The inclusion of the $k t$ FEs in column (6) does not change the estimation results at all as compared to column (5). This implies that, once we have accounted for unobserved factors as well as observed covariates, the PSA, FTA, and CU variables may not be correlated with sector specific factors. The FE estimation results suggest that forming an FTA is expected to increase the chance of trading a new product between member countries by a negligible $0.6 \%$, while the marginal effect of a CU is $1.2 \%$. Although the marginal effect of CUs is twice as big as that of FTAs, it is still very small in absolute terms.

One distinct result from Table 3 is that for both margins of trade and in all model specifications considered, the impact of CUs is larger than that of FTAs, which in turn is larger than that of PSAs. Among the three types of PTAs, PSA represents the reduction or elimination of tariffs or NTBs on certain products between member countries. In comparison, FTA is a deeper form of integration because in principle it should involve elimination of tariffs on "substantially all" products among the members. Custom union constitutes an even greater economic integration than FTA as it involves, in addition to zero tariffs among the members, a single customs territory, free movement of services, and sometimes a single market with free movement of labor and capital (e.g. the Single European Act of the European Union). In other words, we know as a matter of fact that, the non-tariff changes of CUs entail a bigger cut in trade costs than the non-tariff changes of FTAs. The statistics in Table 2 also demonstrate that is the case for tariffs. The results in Table 3 are also consistent with these facts. 
Another noticeable result from Table 3 is that, the effect of PTAs on the extensive margin is rather small, even for CUs. This finding suggests that the intensive margin is the main channel to reap the gains from economic integration, similar to the finding in Baier et al. (2014).

\subsection{Effects of Tariff and Non-Tariff Changes}

In this section, we separate the effects of tariff and non-tariff changes from PTAs by including a measure of tariffs in the estimations. The results are shown in Table 4. Except for the new tariff variable, $\ln \left(1+\right.$ Tarif $\left.f_{i j k t}\right)$, the specification of each column is the same as its counterpart in Table 3. In this estimation, the tariff variable captures the effects of variable trade costs associated with tariffs, leaving the PTA variables to capture the effects of NTMs.

For the intensive margin, columns (1) to (3) show that the tariff variable is significant at the $1 \%$ level across the OLS and two FE estimations, and has the expected negative sign. According to column (3), which has the most comprehensive set of FEs, a $1 \%$ increase in import prices due to tariff hikes is expected to reduce bilateral trade flows by about $2.3 \%$. For the three PTA variables, because now they capture only the effects of non-tariff changes, which can impact on trade flows either positively or negatively, their expected signs are ambiguous. The PSA variable retains its negative sign but is not significant in all three estimations. The FTA variable is significant at the $1 \%$ level in column (1) but its significance level comes down once FEs are included. In column (3), the variable is significant at the 5\% level. The CU variable is the only PTA variable that remains significant at the $1 \%$ level when we have controlled for FEs.

Comparing with the results in Table 3, once we have accounted for tariff changes and all FEs, the coefficient on the FTA variable has reduced by slightly less than half to 0.035 , while that on the $\mathrm{CU}$ variable is largely the same at 0.54 . These findings seem to suggest that, for FTAs, both tariff and non-tariff changes are important mechanisms of impacting on the intensive margin, while for CUs, non-tariff changes are the main mechanism. However, to compare the effects of tariff and non-tariff changes precisely, we need to make use of the information in Table 2 regarding the 
average tariff cut under each type of PTA. Table 2 indicates that, for our dataset, the average tariff rate among FTA member countries falls by 1.5 percentage points one year after the FTA formation as compared to one year before, and the tariff rate for $\mathrm{CU}$ member countries falls by 3.2 percentage points. Multiplying these figures with the coefficient on the tariff variable (i.e. 2.34), we learn that, on average, the tariff changes associated with the formation of FTAs and CUs will increase the bilateral trade between their member countries by $3.5 \%$ and $7.5 \%$, respectively. ${ }^{8}$ In comparison, non-tariff changes under FTAs and CUs are expected to boost trade flows among member countries by about $3.6 \%$ and $71 \%$, respectively. These figures confirm that for the intensive margin, the impact of FTAs is derived equally from tariff and non-tariff changes, while that of CUs is derived mostly from non-tariff changes.

As for the extensive margin, the results are largely in line with expectations. Consider the results in column (6), which has the most comprehensive set of FEs, a 1\% increase in import prices due to tariff hikes is expected to reduce the chance of two countries trading a new product by $0.12 \%$ on average. Non-tariff changes from PSAs has insignificant impact, statistically or otherwise, on the extensive margin. On the contrary, the coefficients on the FTA and CU variables are significant at the $10 \%$ and $1 \%$ level, respectively. Again, to compare the effects of tariff and non-tariff changes associated with FTAs and CUs, we make use of the information in Table 2. It can be computed that, on average, the tariff changes associated with FTAs and CUs are expected to increase the chance of member countries trading a new product by $0.18 \%$ and $0.39 \%$, respectively. In comparison, non-tariff changes associated with FTAs and CUs are expected to increase the chance of trading a new product by about $0.4 \%$ and $1 \%$, respectively. Therefore, for FTAs, the effect derived from non-tariff changes is about twice as big as that from tariff reduction, while for CUs, it is about 2.5 times as big.

The finding of non-tariff changes being the dominant driver of CUs' impacts on both intensive and extensive margins is consistent with expectations. This is because, as shown in Table 2, countries that are about to form a $\mathrm{CU}$ would have already eliminated most of the tariffs among the

\footnotetext{
${ }^{8}$ If we use the median tariff rates instead, the trade flow gains will be $2.7 \%$ for FTAs and $0.16 \%$ for CUs.
} 
members before taking the final step of integration. Therefore, for CU member countries, it is the non-tariff changes that matter most.

Another clear finding from this section is, reflected in the responses of the two trade margins, that CUs involve a deeper reduction in NTBs than FTAs, which in turn involve a deeper reduction in NTBs than PSAs. In fact, the findings suggest that the trade impact of PSAs, if any, would come entirely from tariff reduction. Moreover, the non-tariff changes associated with CUs and FTAs are, on average, trade promoting. On the contrary, there is no such evidence for PSAs, as the coefficients on its variable are insignificant with the proper control of unobserved factors. It is also worth mentioning that, if a particular type of PTA on average involves a fall (rise) in NTBs, it should increase (decrease) both the intensive and extensive margins, provided that the coefficients are significant and positive (negative) in the first place. The results in Table 3 are consistent with this expectation. In fact, as we will see later, the same is true for almost all estimations reported in this paper. ${ }^{9}$

\subsection{Lag Effects}

In the previous section, some PTA variables are found to be statistically insignificant in the presence of FEs. However, firms may take multiple years to respond to tariff and non-tariff changes. Furthermore, some non-tariff arrangements under a PTA may phase in gradually over a number of years after the PTA's launch. Allowing these possibilities while, at the same time, considering the length of the dataset (17 years), in Table 5 we add a three-year lag term for the tariff and PTA variables, respectively. To generate the lag terms, we take the data of every three years starting from the year 1998. This gives us five-year data points: 1998, 2001, 2004, 2007 and 2010. As a result, the number of observations in Table 5 is only about one-third that in the previous tables. As a result, one should be cautious about comparing the results of Table 5 with others. For brevity, we only report the results for the tariff and PTA variables.

\footnotetext{
${ }^{9}$ Given Egypt has much higher tariff rates than other sample countries, we have also estimated column (3) and (6) after dropping it from the importing country sample. The results remain largely the same.
} 
For the intensive margin, consider column (3), which has incorporated the most comprehensive set of FEs. Similar to the findings in Table 4, the contemporaneous terms of tariff, FTA, and CU are significant at the 5\% level, but not that of PSA. Similarly, only the lag terms of tariff, FTA, and $\mathrm{CU}$ are significant, although that of FTA is significant only at the $10 \%$ level. The coefficient on the contemporaneous term of tariffs is about 2.4 times that on its lag. A $1 \%$ decrease in import prices due to tariff reduction is expected to boost bilateral trade by $1.7 \%$ in the first year of implementation and continue to increase trade by another additional $0.7 \%$ three years later. The finding suggests that, although firms and consumers can adjust to tariff changes immediately within a year, some adjustments still take place three years later. In comparison, non-tariff changes of FTAs are expected to increase bilateral trade flows by $4.2 \%$ in the first year, and an additional $2.9 \%$ three years later. In other words, countries take a longer time to adjust to non-tariff changes associated with FTAs compared to tariff reduction. However, the adjustment to non-tariff changes under a CU takes a longer time still; bilateral trade is expected to increase by $42 \%$ in the first year of a new $\mathrm{CU}$, and continue to increase by another $32 \%$ three years later. The difference in the relative strength of the lag terms between tariff, FTA, and CU may come from the timing of firms' acknowledgement and accessibility of information. Although firms can easily get access to the complete information on tariffs even before the tariff changes, it may take a longer time for firms to get full information on non-tariff changes and make adequate responses to them. Furthermore, as CUs are a deeper form of integration and therefore may involve a wider range of non-tariff changes, the adjustment is more prolonged. Another possible explanation is that some non-tariff arrangements under CUs take longer time to phase in than their counterparts under FTAs.

The results of the extensive margin appear to be somewhat incoherent. Given that an increase in the intensive margin requires firms to scale up production while an increase in the extensive margin require firms to export new products, one would expect the latter to be more time consuming than the former. The results in column (6) suggest that that is true in the case of tariffs. The coefficient on the lag tariff variable is 3.2 times that of its contemporaneous counterpart, as compared to 2.4 times in the case of the intensive margin. The results for the PSA variable are also in line with 
this expectation in that, its contemporaneous term is not significant while that of its lag term is significant at the $10 \%$ level. On the contrary, the contemporaneous term of the $\mathrm{CU}$ variable is significant at the $1 \%$ level while its lag term is not significant at all. For the FTA variable, both the contemporaneous and lag terms are not significant at the standard level. One possible explanation for the unexpected results for CUs is that when a firm export a new product to a market, the product itself is not new, the firm may have sold it in the domestic market or other foreign markets for sometimes. If that is the case, firms can quickly respond to non-tariff changes by exporting a small amount of the new product to test the market and, if proven successful, then to scale up the volume in subsequent years. The expansion in subsequent years is reflected in the results for the intensive margin. Furthermore, as shown in Table 4, the effects of non-tariff changes associated with PTAs on the extensive margin, in general, are weak statistically and economically. As a result, the estimated effects are likely to be more sensitive to different samples. Therefore, one should interpret the extensive margin results with caution.

\subsection{Heterogeneity by Development Status}

In this section, we explore if the effects of tariff and non-tariff changes differ across various groups of country-pairs. We divide countries into developing (DEV) and industrial (IND) following Subramanian and Wei (2007). Negotiation outcomes of NTBs are likely to be affected by the relative bargaining power of the signatories. Being the politically and economically weaker partner, developing countries could be pressured by industrial countries to accept stringent provisions on matters such as intellectual property rights, environment and labor standards that are in favor of the latter. Perroni and Whalley (2000) compare concessions made by trading partners in various recent PTAs and show that notably more concessions are made by the smaller partners. The results are reported in Table 6. For instance, in columns (1) and (2), the dependent variable is the imports by industrial countries from industrial countries ("IND from IND”), and so forth. For brevity, we only present the results for the estimations with the four sets of FEs. There are no results for the PSA variable 
for three groups because their country pairs did not form any PSAs during the sample period.

At first glance, there are a lot of similarities across the results of various pair groups. First of all, tariff reduction is found to have a positive and statistically significant impact on both trade margins for all groups. Also, non-tariff changes associated with FTAs and CUs, as long as they are statistically significant, are found to have positive impacts on both trade margins for all groups. The magnitudes of corresponding coefficients are mostly of the same scale across all groups.

But there are also differences across groups. The trade among developing countries ("DEV from "DEV") as in columns (3) and (4), stand out from the others. It is the only group where PSAs are formed in our sample, meaning that it is behind all the PSA results in this paper. Consistent with the findings in the previous sections, the PSA variable is not significant. This group is also the only one for which non-tariff changes (with FTAs or CUs) have statistically significant effects on the extensive margin. Furthermore, the "IND from IND" is the only group for which nontariff changes associated with FTAs have no significant and positive effect on the intensive margin. Indeed, imports by developing countries tend to respond more strongly to non-tariff changes than imports by industrial countries. In particular, non-tariff changes associated with CUs are expected to increase trade flows by developing member countries by 105\% (column 5) to 129\% (column 3), but to increase trade flows by industrial countries by only $31 \%$ (column 7 ) to $38 \%$ (column 1).

Regarding the hypothesis that developing countries may be disadvantaged in negotiation with industrial countries, we find some evidence to support this. In particular, for the intensive margin estimations, the coefficients on the FTA and CU variables are smaller for the "IND from DEV" subsample than for the "DEV from IND" subsample. This result may indicate that industrial country members are able to gain better access to the markets of their developing country counterparts rather than the other way around under the trade agreements. However, we should also be cautious that differences in the trade flows outcome between the two groups of countries could be attributed to other factors unrelated to negotiation power, such as differences in consumer preferences.

Furthermore, the effect of tariff changes is largest for IND-IND trade for both the intensive and extensive margins, as compared to IND-DEV or DEV-DEV trade. At the same time, as shown 
in Figure 3, the average tariff rate is lowest for IND-IND trade. That is, there seems to be an inverse relationship between the average tariff rate and the effect of tariff changes. ${ }^{10}$ One possible explanation is the following. In industrial countries, the average tariff is low and most products have less or no protection by tariffs compared to the case of developing countries. The remaining protected industries are typically the most vulnerable ones like the agricultural sector, and therefore they may be particularly sensitive to trade liberalization including tariff reduction.

Overall, there is some evidence of heterogeneity across various pair groups, but the degree of heterogeneity is limited for our sample.

\subsection{Sectoral Heterogeneity}

Although we use HS2 level data for our analysis, the results presented thus far are average effects over all products and therefore silent on any potential heterogeneous effects across sectors. In principle, we can estimate the effects of tariff and non-tariff changes for each of the 97 HS2 sectors (known as 'chapters'). However, it is burdensome to comprehend the results for all 97 chapters. Thereby, for the ease of the interpretation of results, we aggregate the 97 chapters in 11 groups as defined in Table 7, and then do group-by-group estimations.

The estimation results for the intensive margin for each of these 11 groups are presented in Table 8. In all estimations, we have controlled for $i j, i t, j t$ and $k t$ FEs. $^{11}$ We can control for $k t$ FEs because the group estimations are still conducted using HS2 level data. The corresponding results for all groups combined are already reported in column (3) of Table 4. For the ease of comparison, we repeat the results for all groups in Table 8. It can be seen that there is huge heterogeneity across groups. The tariff variable is significant and of a negative sign for G3, G4, G6, G8, G10 and G11, and the coefficients for the tariff variable range from -1.59 (G6) to -6.4 (G8), compared to -2.78 for the average effect for all groups combined. The variable is also significant at

\footnotetext{
${ }^{10} \mathrm{We}$ are thankful to the reviewer for pointing this out.

${ }^{11}$ The only exception is G8, which does not include $k t$ FEs. G8 has only two HS2 sectors and thus the inclusion of $k t \mathrm{FE}$ will wipe out all the variables of interest.
} 
the $10 \%$ level for G2, but has an unexpected positive sign; the group covers "prepared foodstuffs". As for the PSA variable, it is only significant for G2 and G11. Its coefficient is negative for G2, and the opposite is true for G11. The FTA variable is significant only for G6 at the $10 \%$ level and G10 at the $1 \%$ level. However, the coefficients on the variable are negative in both cases, implying a rise of NTBs. Regarding the CU variable, it is significant for all groups except for G9 and G11, and only G10 registers a negative coefficient. It can be noticed that the coefficients on the PTA variables are sizable for many groups, implying that non-tariff changes can have an economically large impact on trade flows between member countries for those groups. For instance, PSAs are expected to increase trade flows for G11 by 366\%; and CUs are expected to have a similar level of impact for G2 (344\%), G5 (340\%), G6 (443\%) and G10 (-313\%), and an even higher level of impact for G3 (1195\%).

The estimations results for the extensive margin are reported in Table 9. Once again, there is large heterogeneity across the groups. The tariff variable is significant and of a negative sign for G5, 6 and 8 only. It is also significant for G2, but its sign is unexpectedly positive as in the case of the intensive margin.

The PSA variable is not significant at the standard levels for any group. The FTA variable is significant only for G5 at the 10\% level and G8 and G10 at the 1\% level. The coefficients on the variable are negative in all three cases and their magnitudes are comparable to that for all groups combined. As for the $\mathrm{CU}$ variable, it is significant for all groups except for G9 and G11, and among them only G8 and G10 register a negative coefficient. Regarding the magnitude, G2, G4 and G6 are of the largest coefficients in absolute terms. In particular, the formation of a CU is expected to increase the chance of trading "chemical products, plastic, rubber" products (G4) by 20\%, "prepared foodstuffs" (G2) by 16\%, and "textile and footwears" (G6) by $17 \%$.

It is worth mentioning that, the results for Tables 8 and 9 are fairly consistent with each other. As long as a variable is significant at the standard level, it has the same sign for both trade margins for the same group. For instance, the FTA variable is significant at the 1\% level for G10 in both tables, implying that, on average, FTAs involve a rise of NTBs for this group. The only case 
of inconsistency is the results for the CU variable, which is significant in both tables but of the opposite signs.

Overall, we observe vast differences in sectoral responses to trade liberalization. What drives the differences between those responses could be of interest to both policymakers and industry stakeholders and therefore an important research question for the future.

\section{Conclusion and Discussion}

The GATT allows countries to provide a preferential treatment to a specific trading partner in the form of a CU or an FTA, provided that substantially all tariffs are eliminated on trade between the member countries within a reasonable time frame. A quintessential feature of PTAs is tariff reduction between member countries abiding by the GATT. However, countries often pursue further economic integration through agreements on non-tariff matters. NTMs can either complement tariffs cuts to intensify trade liberalization or substitute tariff cuts to abate it. The relative effects of tariff and non-tariff changes under PTAs on bilateral trade have hitherto not been studied much, probably due to the limitation on data. This paper aims to fill this gap by disentangling the effects of tariff and non-tariff changes under PTAs, using a new dataset on bilateral tariff rates. The dataset covers HS2 level products for 90 importing and 149 exporting countries between 1996 and 2010. The dataset incorporates both MFN and preferential tariffs.

Our results show that PTAs, in general, increase both the extensive margin (measured in the probability of trading a new product) and the intensive margin (measured in percentage changes of trade flows) between member countries, and both tariff and non-tariff changes contribute to such increases. The finding indicates that countries' trade liberalization through PTAs is beyond what the GATT initially aimed to accomplish through tariff eliminations. The finding also implies that, on average, non-tariff changes under PTAs do not lead to higher NTBs. We also find that the impact of non-tariff changes, as expected, increases with the level of trade integration. For our dataset, non-tariff changes of PSAs do not have any discernible effects on trade margins, the impact 
of non-tariff changes under FTAs is statistically discernible but economically modest, and that of CUs is the only one that is significant in both statistical and economic terms. The trade impact of FTAs is derived from both tariff and non-tariff changes. On the contrary, the trade effects of CUs stem mostly from non-tariff changes, because their member countries have eliminated most if not all tariffs within the club prior to the formation of a CU. Furthermore, we find that the intensive margin responds to tariff changes faster than to non-tariff changes, and its response to non-tariff changes is quicker under FTAs than under CUs. We obtain some tentative evidence to support the argument that, in PTA negotiations between industrial and developing countries, the former tend to be in a more powerful position and come out with a better deal than the latter. We also find large heterogeneity across sectors.

Our results are largely in line with Baier et al. (2014), who show that PTAs have significant, positive effects on trade flows and both trade margins. Of course, one should be cautious about comparing our results with others' because of large differences of the samples, especially regarding time and countries coverage. In particular, our sample is restricted to WTO member countries while others' typically consist of both WTO member and non-member countries. As shown in Handley (2012), WTO membership can help reduce uncertainty in the international trading environment faced by member countries, and this may affect the response of a country toward further trade liberalization changes.

By way of concluding the paper, we would like to point out that a limitation of our analysis and its implications for the direction of future research. In the current paper, if two countries have signed more than one trade agreement of the same type, e.g. a bilateral FTA in one year and another FTA in the same or a later year, we do not count the second FTA as a new one. This is not an issue if the second one is of a shallower and narrower scope of NTA than the first one, but it would create issues if the opposite is true. A thorough treatment of this issue will require one to count and differentiate each trade agreement signed by any two countries. Such dataset may also allow researchers to unearth new dimensions of heterogeneity across PTAs such as whether the impact of a PTA depends on the number of member countries. Furthermore, while we find 
heterogeneous effects across sectors, we have not probed potential mechanisms behind the results. Specifically, as we represent all types of PTAs using dummy variables, the heterogeneous effects found in our paper could reflect both heterogeneity in the content of agreements for each sector and heterogeneity in the responses toward NTM rules by each sector. Our estimation results are not able to tell which one is the main driver of the sector heterogeneity. We leave this question for future studies. 


\section{References}

Anderson, J. E. and VAN Wincoop, E. (2003). Gravity with Gravitas: A Solution to the Border Puzzle. American Economic Review, 93 (1), 170-192.

AngRist, D. and PischKe, J.-S. (2009). Mostly harmless econometrics princeton. Princeton University.

Arkolakis, C., Costinot, A. and Rodriguez-Clare, A. (2012). New Trade Models, Same Old Gains? American Economic Review, 102 (1), 94-130.

Bacchetta, M. and Beverelli, C. (2012). Non-tariff measures and the wto.

Bagwell, K. and Staiger, R. W. (2002). The Economics of the World Trading System. Cambridge, MA and London, UK: MIT Press.

BAiER, S. L. and Bergstrand, J. H. (2007). Do free trade agreements actually increase members' international trade? Journal of International Economics, 71 (1), 72-95.

— and — (2009). Estimating the effects of free trade agreements on international trade flows using matching econometrics. Journal of International Economics, 77 (1), 63-76.

-, - and FEnG, M. (2014). Economic integration agreements and the margins of international trade. Journal of International Economics, 93 (2), 339-350.

Bergsten, F. (1997). American politics, global trade. Economist, pp. 23-26.

Bernard, A., Jensen, J. B., Redding, S. J. and Schott, P. K. (2009). The margins of us trade. American Economic Review, 99 (2), 487-493.

Broda, C. and Weinstein, D. E. (2006). Globalization and the Gains from Variety. TheQuarterly Journal of Economics, 121 (2), 541-585. 
Chaney, T. (2008). Distorted Gravity: The Intensive and Extensive Margins of International Trade. American Economic Review, 98 (4), 1707-1721.

Cheong, J., Kwak, D. W. and Tang, K. K. (2015a). Can Trade Agreements Curtail Trade Creation and Prevent Trade Diversion? Review of International Economics, 23 (2), 221-238.

—, - and - (2015b). Heterogeneous effects of preferential trade agreements: How does partner similarity matter? World Development, 66, 222-236.

DutT, P., Minov, I. and VAn ZANDt, T. (2013). The effect of WTO on the extensive and the intensive margins of trade. Journal of International Economics forthcoming, 91 (2), 204-219.

Eaton, J. and Kortum, S. (2002). Technology, geography, and trade. Econometrica, 70 (5), $1441-1479$.

Egger, P. and Pfaffermayr, M. (2003). The proper panel econometric specification of the gravity equation: A three-way model with bilateral interaction effects. Empirical Economics, 28 (3), 571-580.

Eicher, T. S., Henn, C. and Papageorgiou, C. (2012). Trade creation and diversion revisited: Accounting for model uncertainty and natural trading partner effects. Journal of Applied Econometrics, 27 (June 2010), 296-321.

Foster, N., Poeschl, J. and Stehrer, R. (2011). The impact of Preferential Trade Agreements on the margins of international trade. Economic Systems, 35 (1), 84-97.

Ghosh, S. and YAmARIK, S. (2004). Are regional trading arrangements trade creating? An application of extreme bounds analysis. Journal of International Economics, 63 (2), 369-395.

HANDLEY, K. (2012). Exporting under trade policy uncertainty: theory and evidence. Tech. rep., Standford University. 
Kehoe, T. J. and RuhL, K. J. (2013). American Economic Review. Journal of Political Economy, $121(2), 358-392$.

Limao, N. and Tovar, P. (2011). Policy choice: Theory and evidence from commitment via international trade agreements. Journal of International Economics, 85 (2), 186-205.

Magee, C. S. (2003). Endogenous preferential trade agreements: an empirical analysis. Contributions to Economic Analysis and Policy, 21 (2), Article 15.

Magee, C. S. P. (2008). New measures of trade creation and trade diversion. Journal of International Economics, 75 (2), 349-362.

Melitz, M. J. (2003). The impact of trade on intra-industry reallocations and aggregate industry productivity. Econometrica, 71 (6), 1695-1725.

Neyman, J. and ScotT, E. L. (1948). Consistent estimates based on partially consistent observations. Econometrica: Journal of the Econometric Society, pp. 1-32.

Perroni, C. and Whalley, J. (2000). The new regionalism: trade liberalization or insurance? Canadian Journal of Economics, 33 (1), 1-24.

RAY, E. J. (1981). The determinants of tariff and nontariff trade restrictions in the united states. Journal of Political Economy, 89 (1), 105-121.

Subramanian, A. and WeI, S. J. (2007). The WTO promotes trade, strongly but unevenly. Journal of International Economics, 72 (3), 151-175.

TREFLER, D. (2004). The long and short of the canada-u. s. free trade agreement. American Economic Review, 94 (4), 870-895.

Wooldridge, M. (2002). Economietric analysis of cross section and panel data. Cambridge, MA, US: MIT Press. 
WTO (2012). World trade report-trade and public policies: a closer look at non-tariff measures in the 21 st century. Tech. rep., World Trade Organzsation, Geneva, Switzerland. 
Figure 1: Tariff (Simple Average)

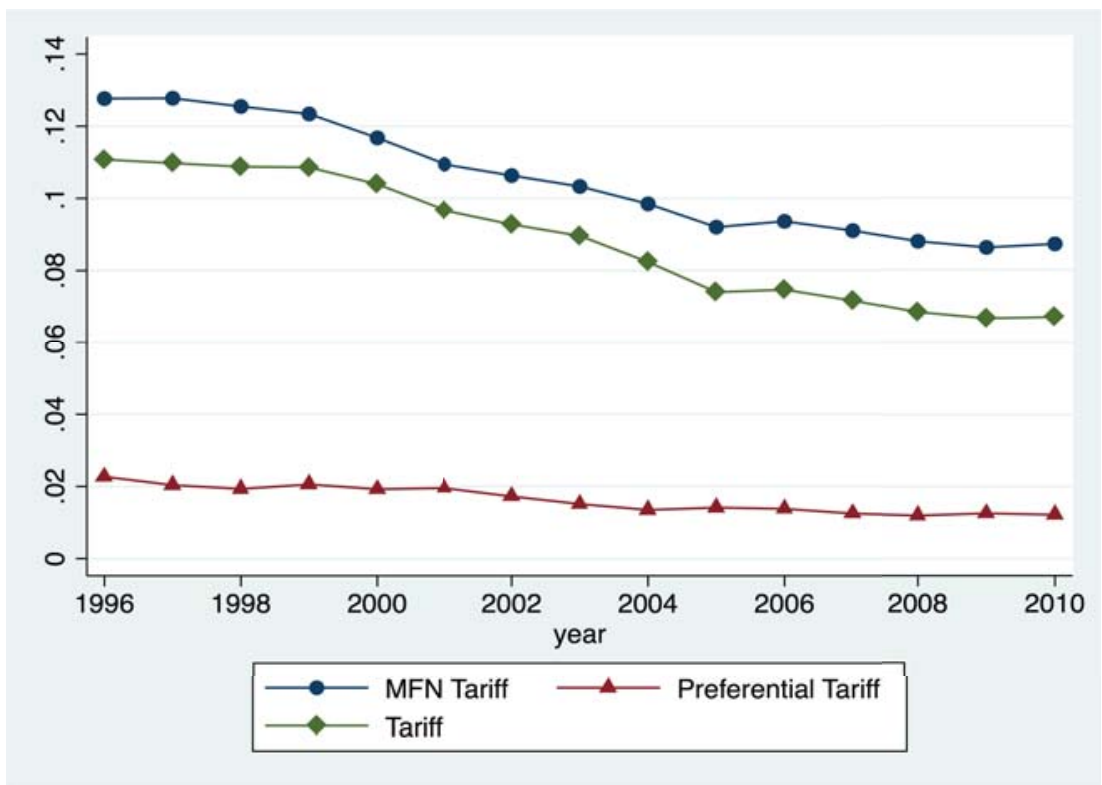

Figure 2: Tariff across sectors: Year 1996 and Year 2010
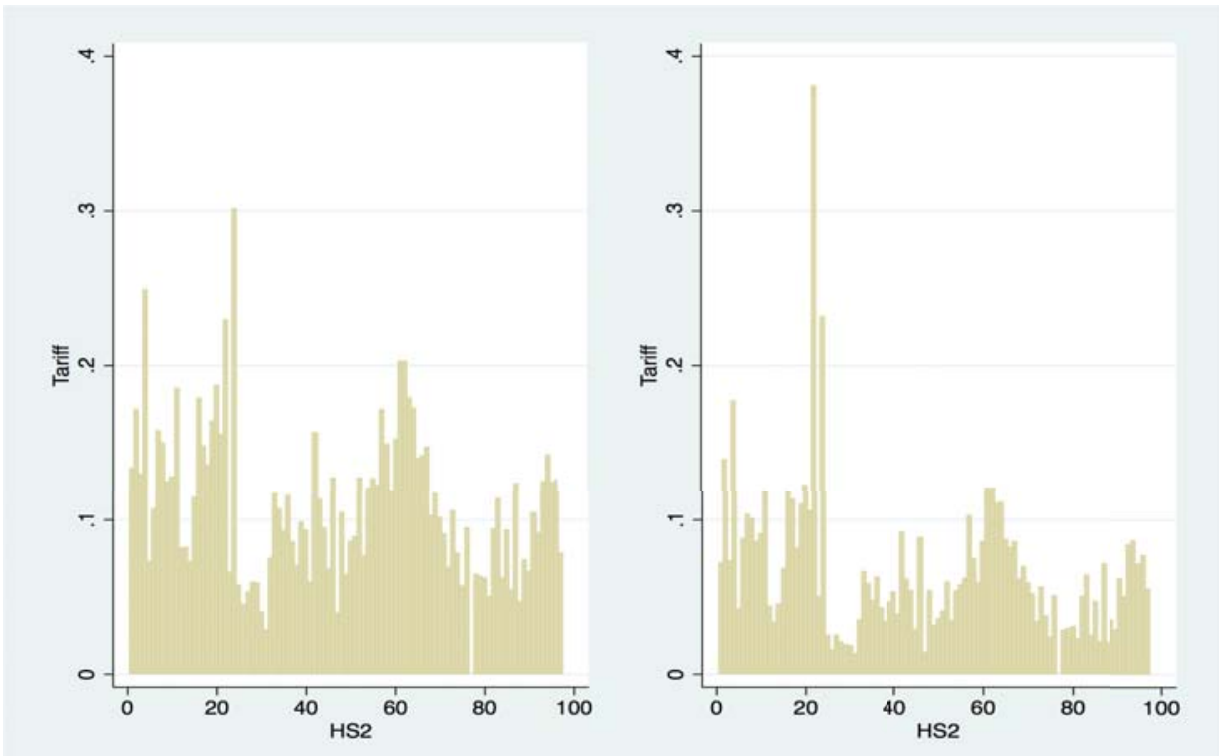

*Note: The higher tariff level on HS2 sector 22 in 2010 is due to the new entry of Egypt in year 2006 into our dataset , where its tariff level on sector 22 (e.g. spirits) is $1,686 \%$. 
Figure 3: Distribution of Tariff: Year 1996 and Year 2010

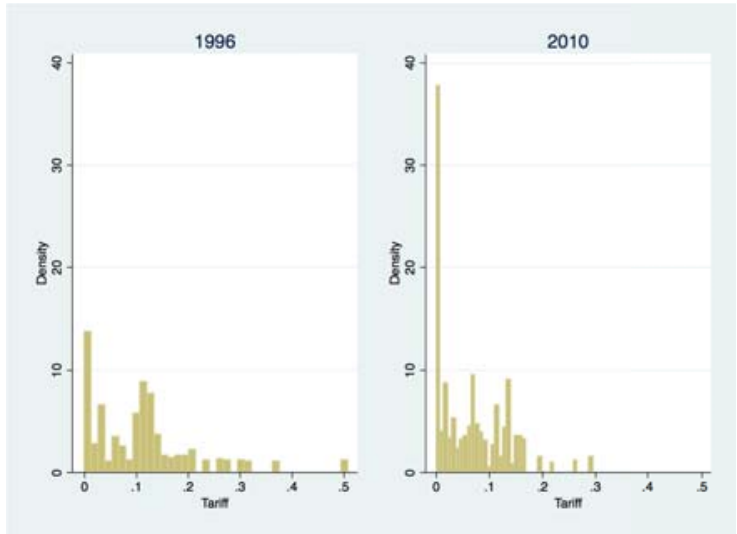

(a) All samples

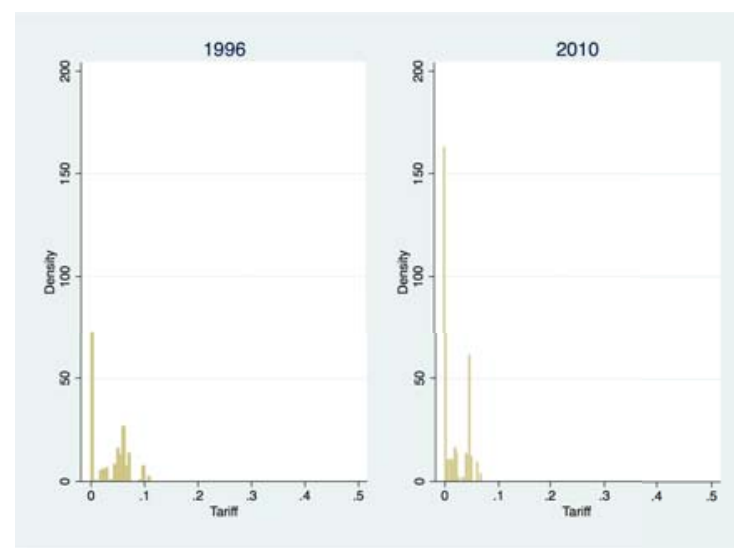

(b) Industrial against Industrial

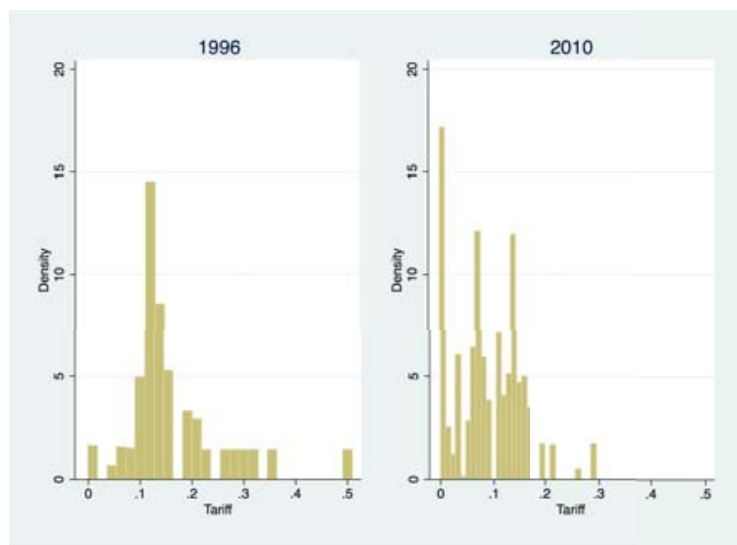

(d) Developing against Industrial

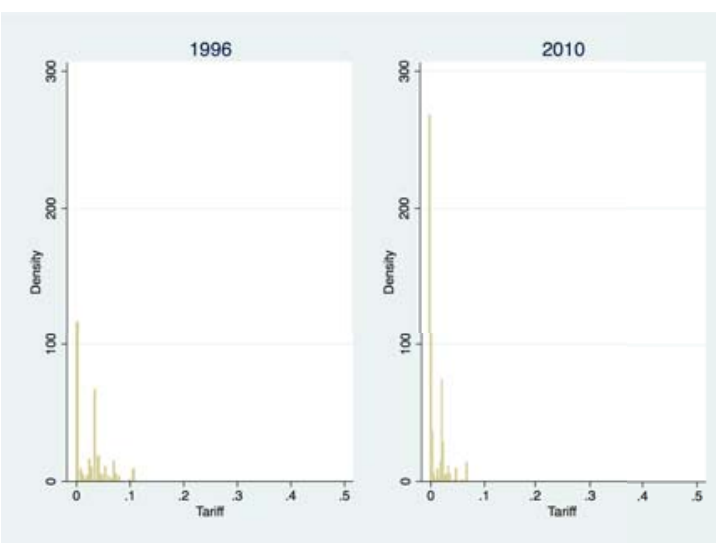

(c) Industrial against Developing

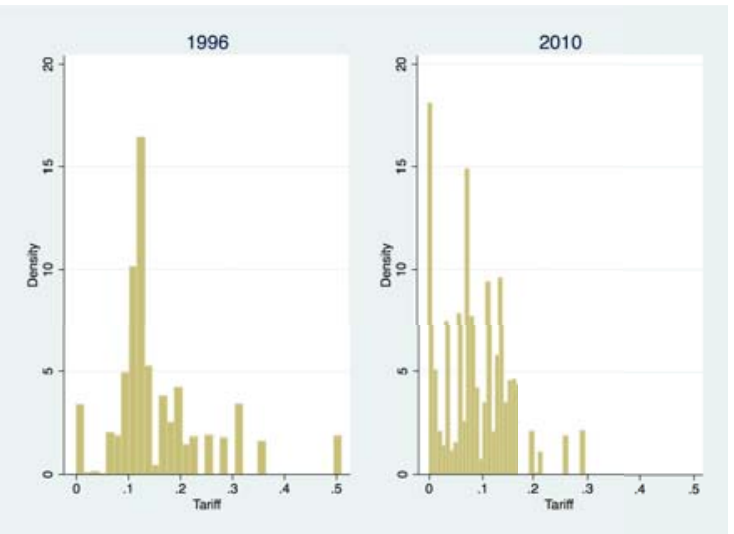

(e) Developing against Developing 
Table 1: Summary Statistics

\begin{tabular}{cccccc}
\hline Variable & Median & Mean & Std.Dev & Min & Max \\
\hline Imports (USD \$1,000) & 133 & 23,256 & $3.8 \times 10^{5}$ & 0 & $1.1 \times 10^{8}$ \\
Extensive Margin & 0.00 & 0.29 & 0.46 & 0 & 1 \\
Tariff (HS2) & 0.05 & 0.09 & 0.17 & 0.00 & 16.86 \\
MFN Tariff (HS2) & 0.07 & 0.10 & 0.18 & 0.00 & 16.86 \\
FTA Tariff (HS2) & 0.00 & 0.02 & 0.05 & 0.00 & 6.75 \\
PSA & 0.00 & 0.08 & 0.28 & 0 & 1 \\
FTA & 0.00 & 0.08 & 0.28 & 0 & 1 \\
CU & 0.00 & 0.05 & 0.22 & 0 & 1 \\
\hline
\end{tabular}

Table 2: Tariff Rate (\%) Among Trade Agreements Partner Countries

\begin{tabular}{lcccccccc}
\hline & \# obs. & Mean & S.D. & Min & 0.25 quantile & 0.5 quantile & 0.75 quantile & Max \\
\hline PSA(-1) & 1056 & 17.54 & 13.22 & 0.00 & 8.73 & 13.62 & 24.16 & 165.62 \\
PSA(+1) & 1056 & 16.44 & 15.16 & 0.00 & 8.00 & 12.16 & 21.36 & 220.27 \\
PSA(+5) & 768 & 13.60 & 14.44 & 0.00 & 7.10 & 10.85 & 16.48 & 210.50 \\
& & & & & & & & \\
FTA(-1) & 132,682 & 7.07 & 17.45 & 0.00 & 0.00 & 1.34 & 9.36 & 1686.36 \\
FTA(+1) & 128,265 & 5.60 & 16.72 & 0.00 & 0.00 & 0.17 & 6.05 & 1685.50 \\
FTA(+5) & 61,048 & 4.95 & 13.30 & 0.00 & 0.00 & 0.11 & 3.44 & 418.06 \\
& & & & & & & & \\
CU(-1) & 51,552 & 3.65 & 8.94 & 0.00 & 0.00 & 0.07 & 4.00 & 169.33 \\
CU(+1) & 51,552 & 0.43 & 2.02 & 0.00 & 0.00 & 0.00 & 0.00 & 83.96 \\
CU(+5) & 41,184 & 0.10 & 1.13 & 0.00 & 0.00 & 0.00 & 0.00 & 83.96 \\
\hline
\end{tabular}

Note: (-1), (+1), and (+5) denote one year before, one year after, and five years after the formation of a PTA. The number of observations for FTA $(+1)$ is smaller than that for FTA $(-1)$ because there are some FTAs formed in the last sample year, 2010, for which there are no observations for FTA(+1) and FTA(+5). 
Table 3: Preferential Trade Agreement Effects

\begin{tabular}{|c|c|c|c|c|c|c|}
\hline & \multicolumn{3}{|c|}{ Intensive margin } & \multicolumn{3}{|c|}{ Extensive margin } \\
\hline & (1) & (2) & (3) & (4) & (5) & (6) \\
\hline PSA & $\begin{array}{c}-0.097 * * \\
(0.047)\end{array}$ & $\begin{array}{l}-0.053 \\
(0.04)\end{array}$ & $\begin{array}{l}-0.054 \\
(0.042)\end{array}$ & $\begin{array}{c}-0.044 * * * \\
(0.006)\end{array}$ & $\begin{array}{l}-0.011 \\
(0.012)\end{array}$ & $\begin{array}{l}-0.011 \\
(0.012)\end{array}$ \\
\hline FTA & $\begin{array}{c}0.198 * * * \\
(0.039)\end{array}$ & $\begin{array}{c}0.054 * * * \\
(0.016)\end{array}$ & $\begin{array}{c}0.060 * * * \\
(0.016)\end{array}$ & $\begin{array}{c}0.094 * * * \\
(0.005)\end{array}$ & $\begin{array}{c}0.006^{* *} \\
(0.002)\end{array}$ & $\begin{array}{c}0.006^{* *} \\
(0.002)\end{array}$ \\
\hline $\mathrm{CU}$ & $\begin{array}{c}0.650 * * * \\
(0.046)\end{array}$ & $\begin{array}{c}0.585 * * * \\
(0.028)\end{array}$ & $\begin{array}{c}0.582 * * * \\
(0.028)\end{array}$ & $\begin{array}{c}0.140 * * * \\
(0.007)\end{array}$ & $\begin{array}{c}0.012 * * * \\
(0.004)\end{array}$ & $\begin{array}{c}0.012 * * * \\
(0.004)\end{array}$ \\
\hline lgdp1 & $\begin{array}{c}0.683 * * * \\
(0.009)\end{array}$ & & & $\begin{array}{c}0.047 * * * \\
(0.001)\end{array}$ & & \\
\hline $\operatorname{lgdp} 2$ & $\begin{array}{c}0.817 * * * \\
(0.008)\end{array}$ & & & $\begin{array}{c}0.100 * * * \\
(0.001)\end{array}$ & & \\
\hline $\operatorname{lgdppc1}$ & $\begin{array}{c}0.127 * * * \\
(0.015)\end{array}$ & & & $\begin{array}{c}0.020 * * * \\
(0.001)\end{array}$ & & \\
\hline $\operatorname{lgdppc} 2$ & $\begin{array}{c}0.116^{* * * *} \\
(0.013)\end{array}$ & & & $\begin{array}{c}0.019 * * * \\
(0.001)\end{array}$ & & \\
\hline contig & $\begin{array}{c}0.889 * * * \\
(0.076)\end{array}$ & & & $\begin{array}{c}0.101 * * * \\
(0.014)\end{array}$ & & \\
\hline comcol & $\begin{array}{c}0.540 * * * \\
(0.075)\end{array}$ & & & $\begin{array}{c}0.038 * * * \\
(0.006)\end{array}$ & & \\
\hline comleg & $\begin{array}{c}0.376^{* * *} \\
(0.03)\end{array}$ & & & $\begin{array}{c}0.026^{* * * *} \\
(0.003)\end{array}$ & & \\
\hline ldist & $\begin{array}{c}-0.772 * * * \\
-0.019\end{array}$ & & & $\begin{array}{c}-0.077 * * * \\
(0.002)\end{array}$ & & \\
\hline Constant & $\begin{array}{c}-9.713 * * * \\
-0.265\end{array}$ & & & $\begin{array}{c}-1.027 * * * \\
(0.027)\end{array}$ & & \\
\hline Fixed effects & None & $i j, i t, j t$ & $i j, i t, j t, k t$ & None & $i j, i t, j t$ & $i j, i t, j t, k t$ \\
\hline $\mathrm{N}$ & $4,524,919$ & $4,524,919$ & $4,524,919$ & $15,349,068$ & $15,349,068$ & $15,349,068$ \\
\hline R-sq & 0.297 & 0.015 & 0.231 & 0.358 & 0.038 & 0.153 \\
\hline
\end{tabular}

Note: $* * *, * * *$ significant at the 10,5 , and 1 percent level, respectively; robust standard errors clustered by countrypair. 
Table 4: Effects of Tariff and Non-tariff Changes

\begin{tabular}{|c|c|c|c|c|c|c|}
\hline & \multicolumn{3}{|c|}{ Intensive margin } & \multicolumn{3}{|c|}{ Extensive margin } \\
\hline & (1) & (2) & (3) & (4) & (5) & (6) \\
\hline Tariff & $\begin{array}{c}-1.731 * * * \\
(0.098)\end{array}$ & $\begin{array}{c}-2.602 * * * \\
(0.088)\end{array}$ & $\begin{array}{c}-2.340 * * * \\
(0.089)\end{array}$ & $\begin{array}{c}-0.107 * * * * \\
(0.008)\end{array}$ & $\begin{array}{c}-0.029 * * * \\
(0.004)\end{array}$ & $\begin{array}{c}-0.122 * * * \\
(0.004)\end{array}$ \\
\hline PSA & $\begin{array}{l}-0.048 \\
(0.047)\end{array}$ & $\begin{array}{l}-0.032 \\
(0.039)\end{array}$ & $\begin{array}{l}-0.036 \\
(0.041)\end{array}$ & $\begin{array}{c}-0.042 * * * \\
(0.006)\end{array}$ & $\begin{array}{l}-0.010 \\
(0.012)\end{array}$ & $\begin{array}{l}-0.009 \\
(0.012)\end{array}$ \\
\hline FTA & $\begin{array}{c}0.165 * * * \\
(0.038)\end{array}$ & $\begin{array}{l}0.026^{*} \\
(0.016)\end{array}$ & $\begin{array}{c}0.035^{* *} \\
(0.015)\end{array}$ & $\begin{array}{c}0.092 * * * \\
(0.005)\end{array}$ & $\begin{array}{c}0.005^{* *} \\
(0.002)\end{array}$ & $\begin{array}{l}0.004 * \\
(0.002)\end{array}$ \\
\hline $\mathrm{CU}$ & $\begin{array}{c}0.565 * * * \\
(0.046)\end{array}$ & $\begin{array}{c}0.535 * * * \\
(0.028)\end{array}$ & $\begin{array}{c}0.535 * * * \\
(0.028)\end{array}$ & $\begin{array}{c}0.134 * * * \\
(0.007)\end{array}$ & $\begin{array}{c}0.012 * * * \\
(0.004)\end{array}$ & $\begin{array}{c}0.010^{* * * *} \\
(0.004)\end{array}$ \\
\hline $\operatorname{lgdp} 1$ & $\begin{array}{c}0.685^{* * * *} \\
(0.009)\end{array}$ & & & $\begin{array}{c}0.047 * * * \\
(0.001)\end{array}$ & & \\
\hline lgdp2 & $\begin{array}{c}0.820 * * * \\
(0.008)\end{array}$ & & & $\begin{array}{c}0.100 * * * \\
(0.001)\end{array}$ & & \\
\hline $\operatorname{lgdppc1}$ & $\begin{array}{c}0.062 * * * \\
(0.015)\end{array}$ & & & $\begin{array}{c}0.016 * * * \\
(0.001)\end{array}$ & & \\
\hline $\operatorname{lgdppc} 2$ & $\begin{array}{c}0.126 * * * \\
(0.013)\end{array}$ & & & $\begin{array}{c}0.019 * * * \\
(0.001)\end{array}$ & & \\
\hline contig & $\begin{array}{c}0.867 * * * \\
(0.076)\end{array}$ & & & $\begin{array}{c}0.098 * * * \\
(0.014)\end{array}$ & & \\
\hline comcol & $\begin{array}{c}0.567 * * * \\
(0.075)\end{array}$ & & & $\begin{array}{c}0.040 * * * \\
(0.006)\end{array}$ & & \\
\hline comleg & $\begin{array}{c}0.372 * * * \\
(0.030)\end{array}$ & & & $\begin{array}{c}0.026 * * * \\
(0.003)\end{array}$ & & \\
\hline ldist & $\begin{array}{c}-0.770 * * * \\
(0.019)\end{array}$ & & & $\begin{array}{c}-0.077 * * * \\
(0.002)\end{array}$ & & \\
\hline Constant & $\begin{array}{c}-9.167 * * * \\
(0.264)\end{array}$ & & & $\begin{array}{c}-0.986 * * * \\
(0.028)\end{array}$ & & \\
\hline $\begin{array}{l}\text { Fixed } \\
\text { effects }\end{array}$ & None & $i j, i t, j t$ & $i j, i t, j t, k t$ & None & $i j, i t, j t$ & $i j, i t, j t, k t$ \\
\hline $\mathrm{N}$ & $4,524,919$ & $4,524,919$ & $4,524,919$ & $15,349,068$ & $15,349,068$ & $15,349,068$ \\
\hline R-sq & 0.299 & 0.018 & 0.233 & 0.359 & 0.038 & 0.154 \\
\hline
\end{tabular}

Note: * significant at the 10 percent level; **significant at the 1 percent level; robust standard errors clustered by country-pair. 
Table 5: Lagged Effects

\begin{tabular}{|c|c|c|c|c|c|c|}
\hline & \multicolumn{3}{|c|}{ Intensive margin } & \multicolumn{3}{|c|}{ Extensive margin } \\
\hline & $(1)$ & $(2)$ & (3) & (4) & $(5)$ & (6) \\
\hline \multirow[t]{2}{*}{ Tariff } & $-2.314 * * *$ & $-2.272 * * *$ & $-1.720 * * *$ & $-0.046 * * *$ & $-0.084 * * *$ & $-0.100 * * *$ \\
\hline & $(0.158)$ & $(0.124)$ & $(0.117)$ & $(0.015)$ & $(0.007)$ & $(0.006)$ \\
\hline \multirow[t]{2}{*}{ lag_Tariff } & 0.231 & $-0.552 * * *$ & $-0.723 * * *$ & $-0.034 * *$ & $0.060 * * *$ & $-0.031 * * *$ \\
\hline & $(0.144)$ & $(0.103)$ & $(0.103)$ & $(0.016)$ & $(0.006)$ & $(0.006)$ \\
\hline \multirow[t]{2}{*}{ PSA } & 0.174 & -0.059 & -0.037 & -0.023 & 0.006 & 0.007 \\
\hline & $(0.148)$ & $(0.056)$ & $(0.056)$ & $(0.024)$ & $(0.015)$ & $(0.015)$ \\
\hline \multirow[t]{2}{*}{ lag_PSA } & -0.195 & -0.036 & -0.053 & -0.020 & $-0.028 *$ & $-0.028 *$ \\
\hline & $(0.146)$ & $(0.052)$ & $(0.053)$ & $(0.024)$ & $(0.014)$ & $(0.014)$ \\
\hline \multirow[t]{2}{*}{ FTA } & $0.227 * * *$ & 0.032 & $0.041 * *$ & $0.060 * * *$ & 0.002 & 0.002 \\
\hline & $(0.039)$ & $(0.021)$ & $(0.020)$ & $(0.005)$ & $(0.003)$ & $(0.003)$ \\
\hline \multirow[t]{2}{*}{ lag_FTA } & 0.032 & 0.029 & $0.029 *$ & $0.050 * * *$ & -0.001 & -0.002 \\
\hline & $(0.041)$ & $(0.018)$ & $(0.017)$ & $(0.006)$ & $(0.003)$ & $(0.003)$ \\
\hline \multirow[t]{2}{*}{$\mathrm{CU}$} & $0.485 * * *$ & $0.346^{* * * *}$ & $0.352 * * *$ & $0.142 * * *$ & $0.014 * * *$ & $0.014 * * *$ \\
\hline & $(0.050)$ & $(0.044)$ & $(0.043)$ & $(0.008)$ & $(0.005)$ & $(0.005)$ \\
\hline \multirow[t]{2}{*}{ lag_CU } & $0.206 * * *$ & $0.293 * * *$ & $0.281 * * *$ & 0.005 & -0.000 & -0.002 \\
\hline & $(0.049)$ & $(0.030)$ & $(0.030)$ & $(0.007)$ & (0.004) & (0.004) \\
\hline $\begin{array}{l}\text { Fixed } \\
\text { effects }\end{array}$ & None & $i j, i t, j t$ & $i j, i t, j t, k t$ & None & $i j, i t, j t$ & $i j, i t, j t, k t$ \\
\hline $\mathrm{N}$ & $1,272,135$ & $1,272,135$ & $1,272,135$ & $4,020,295$ & $4,020,295$ & $4,020,295$ \\
\hline R-sq & 0.315 & 0.013 & 0.234 & 0.367 & 0.016 & 0.147 \\
\hline
\end{tabular}

Note: $* * *, * * *$ significant at the 10,5 , and 1 percent level, respectively; robust standard errors clustered by countrypair. 
Table 6: Heterogeneity by Development Status

\begin{tabular}{|c|c|c|c|c|c|c|c|c|}
\hline & \multicolumn{2}{|c|}{ IND from IND } & \multicolumn{2}{|c|}{ DEV from DEV } & \multicolumn{2}{|c|}{ DEV from IND } & \multicolumn{2}{|c|}{ IND from DEV } \\
\hline & Intensive & Extensive & Intensive & Extensive & Intensive & Extensive & Intensive & Extensive \\
\hline & (1) & (2) & (3) & (4) & (5) & (6) & (7) & $(8)$ \\
\hline Tariff & $\begin{array}{c}-2.412 * * * \\
(0.267)\end{array}$ & $\begin{array}{c}-0.121 * * * \\
(0.025)\end{array}$ & $\begin{array}{c}-1.784 * * * \\
(0.121)\end{array}$ & $\begin{array}{c}-0.083 * * * \\
(0.005)\end{array}$ & $\begin{array}{c}-2.044 * * * \\
(0.156)\end{array}$ & $\begin{array}{c}-0.130 * * * \\
(0.013)\end{array}$ & $\begin{array}{c}-2.184 * * * \\
(0.288)\end{array}$ & $\begin{array}{c}-0.056^{* * *} * \\
(0.013)\end{array}$ \\
\hline PSA & & & $\begin{array}{c}0.030 \\
(0.051)\end{array}$ & $\begin{array}{c}0.005 \\
(0.013)\end{array}$ & & & & \\
\hline FTA & $\begin{array}{c}-0.010 \\
(0.054)\end{array}$ & $\begin{array}{c}0.004 \\
(0.012)\end{array}$ & $\begin{array}{c}0.077 * * \\
(0.035)\end{array}$ & $\begin{array}{c}0.015^{* * * *} \\
(0.004)\end{array}$ & $\begin{array}{c}0.095 * * * \\
(0.027)\end{array}$ & $\begin{array}{l}-0.008 \\
(0.006)\end{array}$ & $\begin{array}{c}0.072 * * * \\
(0.026)\end{array}$ & $\begin{array}{c}0.002 \\
(0.003)\end{array}$ \\
\hline $\mathrm{CU}$ & $\begin{array}{c}0.324 * * * \\
(0.109)\end{array}$ & $\begin{array}{l}-0.003 \\
(0.015)\end{array}$ & $\begin{array}{c}0.827 * * * \\
(0.058)\end{array}$ & $\begin{array}{c}0.030 * * * \\
(0.008)\end{array}$ & $\begin{array}{c}0.717 * * * \\
(0.060)\end{array}$ & $\begin{array}{c}-0.017 \\
(0.011)\end{array}$ & $\begin{array}{c}0.267 * * * \\
(0.052)\end{array}$ & $\begin{array}{l}-0.002 \\
(0.008)\end{array}$ \\
\hline $\mathrm{N}$ & 646,536 & 801,404 & $1,591,991$ & $8,674,767$ & $1,064,529$ & $1,888,761$ & $1,221,863$ & $3,984,136$ \\
\hline R-sq & 0.467 & 0.262 & 0.201 & 0.136 & 0.409 & 0.289 & 0.200 & 0.170 \\
\hline
\end{tabular}

Note: $*, * *, * * *$ significant at the 10,5 , and 1 percent level, respectively; robust standard errors clustered by countrypair. All estimations include and FEs. 
Table 7: HS Classification by Section

\begin{tabular}{cccc}
\hline Group & HS Sections & HS2 Codes & Simple Descriptions \\
\hline 1 & Sections I, II and III & $01-15$ & Live Animals, Vegetable Products \\
2 & Section IV & $16-24$ & Prepared Foodstuffs \\
3 & Section V & $25-27$ & Mineral Products \\
4 & Sections VI, VII & $28-40$ & Chemical Products, Plastic, Rubber \\
5 & Sections VIII, IX, X & $41-49$ & Skins, Leather, Wood \\
6 & Section XI & $50-67$ & Textile and Footwear \\
7 & Sections XIII, XIV, XV & $68-83$ & Plaster, Glass, Base Metals \\
8 & Section XVI & $84-85$ & Machinery, Appliances \\
9 & Section XVII & $86-89$ & Vehicles \\
10 & Section XVIII & $90-92$ & Optical, Watches \\
11 & Section XX & $94-96$ & Furniture, Toys \\
\hline
\end{tabular}


Table 8: Intensive Margin Estimations by Sector

\begin{tabular}{|c|c|c|c|c|c|c|c|c|c|c|c|c|}
\hline & All & G1 & G2 & G3 & G4 & G5 & G6 & G7 & G8 & G9 & G10 & G11 \\
\hline Tariff & $-2.340 * * *$ & -0.649 & $1.988^{*}$ & $-3.580 * *$ & $-2.168 * *$ & 0.794 & $-1.586^{* * * *}$ & -1.424 & $-6.403^{* * *}$ & 1.362 & $-3.748^{* *}$ & $-2.852^{*}$ \\
\hline & $(0.089)$ & $(0.808)$ & (1.165) & (1.644) & $(0.877)$ & $(0.743)$ & $(0.292)$ & (0.964) & $(0.364)$ & (1.169) & (1.558) & (1.517) \\
\hline PSA & $\begin{array}{l}-0.036 \\
(0.041)\end{array}$ & $\begin{array}{c}0.268 \\
(0.305)\end{array}$ & $\begin{array}{c}-0.978 * * * \\
(0.373)\end{array}$ & $\begin{array}{l}-0.245 \\
(0.540)\end{array}$ & $\begin{array}{l}-0.365 \\
(0.263)\end{array}$ & $\begin{array}{c}0.219 \\
(0.321)\end{array}$ & $\begin{array}{l}-0.401 \\
(0.258)\end{array}$ & $\begin{array}{c}0.452 \\
(0.376)\end{array}$ & $\begin{array}{c}0.082 \\
(0.102)\end{array}$ & $\begin{array}{c}0.179 \\
(0.579)\end{array}$ & $\begin{array}{l}-0.379 \\
(0.488)\end{array}$ & $\begin{array}{c}1.539 * * * \\
(0.481)\end{array}$ \\
\hline FTA & $\begin{array}{c}0.035^{* * *} \\
(0.015)\end{array}$ & $\begin{array}{l}-0.137 \\
(0.103)\end{array}$ & $\begin{array}{c}-0.094 \\
(0.187)\end{array}$ & $\begin{array}{c}0.154 \\
(0.307)\end{array}$ & $\begin{array}{l}-0.115 \\
(0.104)\end{array}$ & $\begin{array}{c}0.043 \\
(0.150)\end{array}$ & $\begin{array}{l}-0.217^{*} \\
(0.112)\end{array}$ & $\begin{array}{l}-0.168 \\
(0.110)\end{array}$ & $\begin{array}{c}0.044 \\
(0.032)\end{array}$ & $\begin{array}{l}-0.093 \\
(0.172)\end{array}$ & $\begin{array}{c}-0.545^{* * * *} \\
(0.203)\end{array}$ & $\begin{array}{c}0.075 \\
(0.120)\end{array}$ \\
\hline $\mathrm{CU}$ & $\begin{array}{c}0.535^{* * * *} \\
(0.028)\end{array}$ & $\begin{array}{c}0.490^{* * * *} \\
(0.185)\end{array}$ & $\begin{array}{c}1.490 * * * \\
(0.292)\end{array}$ & $\begin{array}{c}2.561 \text { *** } \\
(0.605)\end{array}$ & $\begin{array}{c}0.740 \text { **** } \\
(0.167)\end{array}$ & $\begin{array}{c}1.481 * * * \\
(0.315)\end{array}$ & $\begin{array}{c}1.489^{* * * *} \\
(0.191)\end{array}$ & $\begin{array}{c}0.468^{\text {** }} \\
(0.202)\end{array}$ & $\begin{array}{c}0.127 * * \\
(0.057)\end{array}$ & $\begin{array}{l}-0.150 \\
(0.351)\end{array}$ & $\begin{array}{c}-1.418 * * * \\
(0.473)\end{array}$ & $\begin{array}{c}0.637 \\
(0.549)\end{array}$ \\
\hline $\mathrm{R}$-sq & 0.233 & 0.199 & 0.266 & 0.209 & 0.386 & 0.456 & 0.316 & 0.333 & 0.142 & 0.146 & 0.482 & 0.160 \\
\hline
\end{tabular}

Note: $* * *, * * *$ significant at the 10,5 , and 1 percent level, respectively; robust standard errors clustered by country-pair. All estimations include and FEs, the only exception is G8, those estimation include, and FEs only, because the group has only two HS2 sectors and so the inclusion of FEs will wipeout all the variables of interests.

$\omega_{0}^{\omega}$

Table 9: Extensive Margin Estimations by Sector

\begin{tabular}{|c|c|c|c|c|c|c|c|c|c|c|c|c|}
\hline & All & G1 & G2 & G3 & G4 & G5 & G6 & G7 & G8 & G9 & G10 & G11 \\
\hline Tariff & $-0.122 * * *$ & -0.051 & $0.236^{* * * *}$ & -0.231 & 0.038 & $-0.116^{* *}$ & $-0.092 * * *$ & 0.028 & $-0.188^{* * * *}$ & -0.119 & -0.099 & -0.134 \\
\hline & $(0.004)$ & $(0.066)$ & $(0.064)$ & $(0.203)$ & $(0.054)$ & $(0.053)$ & $(0.014)$ & $(0.052)$ & $(0.032)$ & $(0.117)$ & (0.109) & (0.111) \\
\hline PSA & $\begin{array}{l}-0.009 \\
(0.012)\end{array}$ & $\begin{array}{l}-0.006 \\
(0.028)\end{array}$ & $\begin{array}{c}0.089 \\
(0.066)\end{array}$ & $\begin{array}{c}0.061 \\
(0.057)\end{array}$ & $\begin{array}{c}0.026 \\
(0.036)\end{array}$ & $\begin{array}{c}0.049 \\
(0.046)\end{array}$ & $\begin{array}{l}-0.025 \\
(0.031)\end{array}$ & $\begin{array}{l}-0.016 \\
(0.030)\end{array}$ & $\begin{array}{l}-0.016 \\
(0.017)\end{array}$ & $\begin{array}{c}-0.008 \\
(0.066)\end{array}$ & $\begin{array}{l}-0.070 \\
(0.061)\end{array}$ & $\begin{array}{c}0.364 \\
(0.244)\end{array}$ \\
\hline FTA & $\begin{array}{l}0.004 * \\
(0.002)\end{array}$ & $\begin{array}{c}0.009 \\
(0.007)\end{array}$ & $\begin{array}{c}0.004 \\
(0.011)\end{array}$ & $\begin{array}{l}-0.024 \\
(0.025)\end{array}$ & $\begin{array}{c}-0.004 \\
(0.009)\end{array}$ & $\begin{array}{l}-0.021 * \\
(0.012)\end{array}$ & $\begin{array}{c}0.013 \\
(0.008)\end{array}$ & $\begin{array}{l}-0.006 \\
(0.008)\end{array}$ & $\begin{array}{c}-0.033^{* * *} * \\
(0.005)\end{array}$ & $\begin{array}{c}-0.014 \\
(0.010)\end{array}$ & $\begin{array}{c}-0.070 * * * \\
(0.016)\end{array}$ & $\begin{array}{l}-0.007 \\
(0.024)\end{array}$ \\
\hline $\mathrm{CU}$ & $\begin{array}{c}0.010 * * * * \\
(0.004)\end{array}$ & $\begin{array}{l}-0.016 \\
(0.013)\end{array}$ & $\begin{array}{c}0.163 * * * * \\
(0.022)\end{array}$ & $\begin{array}{c}0.105^{* * *} \\
(0.045)\end{array}$ & $\begin{array}{c}0.204 * * * \\
(0.017)\end{array}$ & $\begin{array}{c}0.067 * * * * \\
(0.024)\end{array}$ & $\begin{array}{c}0.167 * * * * \\
(0.015)\end{array}$ & $\begin{array}{c}0.086^{* * * *} \\
(0.015)\end{array}$ & $\begin{array}{c}-0.105^{* * * *} \\
(0.010)\end{array}$ & $\begin{array}{c}0.018 \\
(0.044)\end{array}$ & $\begin{array}{c}-0.101 * * * \\
(0.035)\end{array}$ & $\begin{array}{l}-0.021 \\
(0.034)\end{array}$ \\
\hline $\mathrm{R}-\mathrm{sq}$ & 0.154 & 0.078 & 0.067 & 0.053 & 0.222 & 0.273 & 0.120 & 0.123 & 0.184 & 0.062 & 0.163 & 0.040 \\
\hline
\end{tabular}

Note: *,**,*** significant at the 10,5, and 1 percent level, respectively; robust standard errors clustered by country-pair. All estimations include and FEs, the only exception is G8, those estimation include, and FEs only, because the group has only two HS2 sectors and so the inclusion of FEs will wipeout all the variables of interests. 


\section{Appendix}

Table 10: Countries in the sample

\begin{tabular}{|c|c|c|c|c|}
\hline Argentina & Armenia & Australia & Austria & Bangladesh \\
\hline Belgium & Bolivia & Brazil & Bulgaria & Cameroon \\
\hline Canada & Chile & China & Colombia & Costa Rica \\
\hline Croatia & Cuba & Czech Republic & Denmark & Dominican Republic \\
\hline Ecuador & Egypt Arab Rep. & El Salvador & Estonia & Fiji \\
\hline Finland & France & Germany & Greece & Guatemala \\
\hline Honduras & Hungary & Iceland & India & Indonesia \\
\hline Ireland & Israel & Italy & Jamaica & Japan \\
\hline Jordan & Kenya & Korea Rep. & Kuwait & Latvia \\
\hline Lithuania & Luxembourg & Macedonia FYR & Malaysia & Maldives \\
\hline Malta & Mauritius & Mexico & Morocco & Namibia \\
\hline Netherlands & New Zealand & Nicaragua & Niger & Norway \\
\hline Oman & Pakistan & Peru & Philippines & Poland \\
\hline Portugal & Qatar & Romania & Saudi Arabia & Senegal \\
\hline Singapore & Slovak Republic & Slovenia & South Africa & Spain \\
\hline Sri Lanka & Sweden & Switzerland & Thailand & Trinidad and Tobago \\
\hline Tunisia & Turkey & Uganda & Ukraine & United Arab Emirates \\
\hline United Kingdom & United States & Uruguay & Venezuela & Zambia \\
\hline Albania & Angola & Antigua and Barbuda & Bahrain & Barbados \\
\hline Belize & Benin & Botswana & Brunei & Burkina Faso \\
\hline Burundi & Cambodia & Cape Verde & CAR & Chad \\
\hline Congo Dem. & Congo Rep. & Cote d'Ivoire & Cyprus & Djibouti \\
\hline Dominica & Gabon & Gambia & Georgia & Ghana \\
\hline Grenada & Guinea & Guinea-Bissau & Guyana & Haiti \\
\hline Hong Kong & Kyrgyz Republic & Lesotho & Macao & Malawi \\
\hline Mali & Mauritania & Moldova & Mongolia & Mozambique \\
\hline Myanmar & Nepal & Nigeria & Panama & Papua New Guinea \\
\hline Paraguay & Rwanda & Sierra Leone & Solomon Islands & St. Kitts and Nevis \\
\hline St. Lucia & $\begin{array}{l}\text { St. Vincent } \\
\text { and the Grenadines }\end{array}$ & Suriname & Swaziland & Tanzania \\
\hline Togo & Tonga & Vietnam & Zimbabwe & \\
\hline
\end{tabular}

*Notes: CAR is Central African Republic. 90 countries in the upper panel are included as both importing and exporting countries. 59 countries in the lower panel are included as exporting countries only. 